\title{
NEW ROBUST MAIN RUNNER REFRACTORY CASTABLE FOR SEVERE BLAST FURNACE OPERATING CONDITIONS*
}

\author{
Vitor Guarnier Domiciano ${ }^{1}$ \\ Aloísio Simões Ribeiro² \\ Alexander Rabello Ollmann ${ }^{3}$ \\ Humberto Chiaretti Bassalo ${ }^{4}$ \\ Modestino Alves de Moura Brito ${ }^{5}$
}

\begin{abstract}
The need to adjust the monolithic refractories to increasingly severe and unstable Blast Furnace casthouse operating conditions has been a major challenge for refractory suppliers in order to guarantee the runner's safety and its availability for operation. This paper presents the properties of a new robust single line $\mathrm{Al}_{2} \mathrm{O}_{3}-\mathrm{SiC}-\mathrm{C}$ refractory castable developed to endure the severe operating conditions that main runners are facing in today's Blast Furnace casthouse scenario. Practical results during almost one year of testing revealed a significant lower wear speed of the new refractory lining when compared to a standard product.
\end{abstract}

Keywords: Blast furnace; Operating conditions; Main runner; Refractory castable; Wear speed; Corrosion resistance.

1 Engenheiro de Materiais, Mestre em Ciência e Engenharia de Materiais, Pesquisador, Magnesita Refratários $S / A$.

2 Membro da ABM, Engenheiro Metalurgista, Mestre em Engenharia de Materiais, Assistente Técnico, Magnesita Refratários S/A.

3 Engenheiro Metalurgista. Especialista da Área de Redução da Magnesita Refratários S/A.

4 Membro da ABM, Engenheiro Metalurgista e MSc. em Engenharia Cerâmica. Consultor.

5 Engenheiro Metalurgista e MSc. em Engenharia Cerâmica, Diretor Técnico de P\&D, Magnesita Refratários $S / A$.

* Contribuição técnica ao 44 Seminário de Redução de Minério de Ferro e Matérias-primas, $15^{\circ}$ Simpósio Brasileiro de Minério de Ferro e $2^{\circ}$ Simpósio Brasileiro de Aglomeração de Minério de Ferro, 15 a 18 de setembro de 2014, Belo Horizonte, MG, Brasil. 


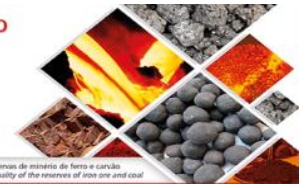

\section{INTRODUCTION}

In recent years, the Brazilian Ironmaking scenario has experienced major changes as a result of the huge competition in the global steel market and the shortage of high grade iron ore and coke deposits. In Blast Furnace, the use of economically competitive raw materials (iron ore, coke, alternative fuels, etc) has allowed a better management of total production costs of hot metal. In the meantime, frequent oscillations in the Blast Furnaces operating conditions (production, casting temperature, slag-rate, slag composition, etc) has been noticed, which has shown a direct impact on the refractories' performance (castables, ramming mixes, taphole clays, etc) used in the casthouse [1-5]. Besides increasing refractory consumption, a dramatically change in the main runner wear profile was observed in some Blast Furnace casthouses leading to an unsafe casting operation mostly because of an increase of the refractory lining wear speed at the metal line [4-8]. In order to guarantee the runner's safety and its availability for operation, a new refractory castable was designed to endure the severe and unstable operating conditions that runners are facing in today's Blast Furnace casthouse scenario.

This paper presents the main properties of a new robust $\mathrm{Al}_{2} \mathrm{O}_{3}-\mathrm{SiC}-\mathrm{C}$ refractory castable developed for main runners. The goal was to improve the castable corrosion resistance at the metal line (slag-metal interface) without harming slag line performance. Thermal shock and oxidation resistances were also enhanced. Practical results during almost one year of testing revealed a significant lower wear speed of the new refractory lining at both metal line and slag line when compared to a standard product.

\section{MATERIALS AND METHODS}

An ultra-low cement containing Al2O3-SiC-C refractory castable commonly used in high production Blast Furnace main runners was the reference basis (standard product) for the development of a new refractory castable. Samples of $230 \times 60 \times 60 \mathrm{~mm}$ were used to determine the main physical properties of the castables after different thermal treatments $\left(110^{\circ} \mathrm{C} / 24 \mathrm{~h}\right.$ and $1400^{\circ} \mathrm{C} / 5 \mathrm{~h}$ - coke breeze): apparent porosity (AP), bulk density (BD) and cold crushing strength (CCS) and hot modulus of rupture (HMOR $-1485^{\circ} \mathrm{C} / 3 \mathrm{~h}$ ). $230 \times 60 \times 60 \mathrm{~mm}$ dried samples were used in the thermal shock test and the elastic modulus (E) values obtained after $0,1,3$ and 5 thermal shock cycles $\left(1200^{\circ} \mathrm{C} / 30 \mathrm{~min}\right)$ were considered to determine the $E(\%)$ loss. The oxidation resistance was evaluated by measuring the oxidized area on the cross section surface of samples after thermal shock test. The corrosion resistance tests were carried out in an induction furnace $\left(\mathrm{IFT}-1600^{\circ} \mathrm{C} / 4 \mathrm{~h}\right)$ and rotary drum furnace (RDT$1650^{\circ} \mathrm{C} / 4 \mathrm{~h}$ ). The former is commonly employed to evaluate the castable's corrosion resistance at the main runner's metal line (slag-metal interface) and the later at the slag line (slag-air interface). The total amount of slag used in a standard corrosion test $(1600 \mathrm{~g})$ was increased $50 \mathrm{wt} . \%(2400 \mathrm{~g})$ by increasing the frequency of granulated Blast Furnace slag addition: Test $1(200 \mathrm{~g} / 30 \mathrm{~min})$ and Test 2 $(200 \mathrm{~g} / 20 \mathrm{~min})$. The residual thickness of 2 prismatic samples were considered to calculate the average corrosion wear (\%) of the Standard Product and the New Castable developed.

\footnotetext{
* Contribuição técnica ao 44 Seminário de Redução de Minério de Ferro e Matérias-primas, 15은 Simpósio Brasileiro de Minério de Ferro e 2o Simpósio Brasileiro de Aglomeração de Minério de Ferro, 15 a 18 de setembro de 2014, Belo Horizonte, MG, Brasil.
} 


\section{RESULTS AND DISCUSSION}

The main guidelines which headed the adjusts carried out in the new refractory castable formulation are presented in Table 1. The challenge was to improve the corrosion resistance but also obtain a good thermal shock and oxidation resistances. The new castable particle size distribution (PSD) was completely modified and the total amount of alumina (Al2O3) was increased. More coarse grains and higher topsize particle were introduced in the formulation. The silicon carbide $(\mathrm{SiC})$ particle size distribution was optimized and its total amount was decreased. A new carbon (C) source with higher oxidation resistance was introduced in the formulation and special attention was given to reduce the amount of raw materials which generate low melting point phases.

Table 1. Guidelines for refractory castable formulation adjusts

\begin{tabular}{c|c|} 
Standard Product & GOAL \\
\cline { 1 - 1 } $\mathrm{Al}_{2} \mathrm{O}_{3}$ & $\begin{array}{r}\text { Improve corrosion, thermal shock and } \\
\text { oxidation resistances }\end{array}$ \\
\cline { 1 - 1 } $\mathrm{SiC}$ & Decrease low melting point phases \\
\hline Others &
\end{tabular}

Figure 1 shows the samples' surface aspect of a standard product and the new castable developed. Table 2 presents the castables' main properties.

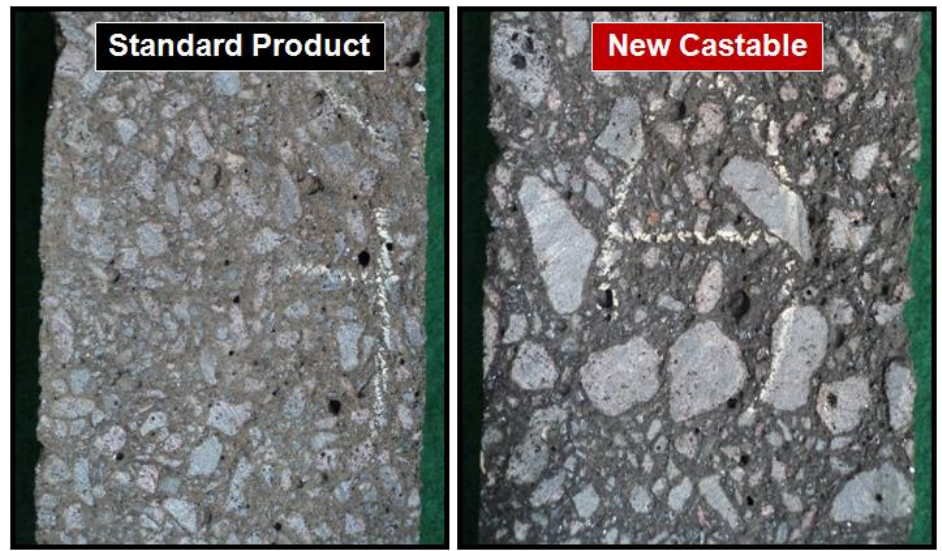

Figure 1: Macrostructure aspects of the refractory castables.

Table 2. Main properties of the castables

\begin{tabular}{|c|c|c|c|}
\hline \multicolumn{2}{|r|}{ Properties } & Standard & New Castable \\
\hline \multicolumn{2}{|c|}{ Water (wt.\%) } & 4.8 & 3.9 \\
\hline \multicolumn{2}{|c|}{ Vibra-flow (mm) - $10^{\prime \prime}$} & 184 & 179 \\
\hline \multirow{3}{*}{ 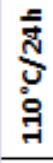 } & $\mathrm{BD}\left(\mathrm{g} / \mathrm{cm}^{3}\right)$ & 2,96 & 3,08 \\
\hline & AP (\%) & 12,2 & 10,2 \\
\hline & $\operatorname{CCS}(\mathrm{MPa})$ & 65,0 & 47,6 \\
\hline \multirow{3}{*}{ 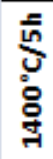 } & $\mathrm{BD}\left(\mathrm{g} / \mathrm{cm}^{3}\right)$ & 3,01 & 3,13 \\
\hline & $\operatorname{AP}(\%)$ & 15,4 & 13,6 \\
\hline & $\mathrm{CCS}(\mathrm{MPa})$ & 90,7 & 63,0 \\
\hline \multicolumn{2}{|c|}{$\mathrm{HMOR} 1485^{\circ} \mathrm{C} / 3 \mathrm{~h}(\mathrm{MPa})$} & 0,5 & 1,2 \\
\hline
\end{tabular}

* Contribuição técnica ao 44 Seminário de Redução de Minério de Ferro e Matérias-primas, 15은 Simpósio Brasileiro de Minério de Ferro e 2ํ Simpósio Brasileiro de Aglomeração de Minério de Ferro, 15 a 18 de setembro de 2014, Belo Horizonte, MG, Brasil. 
When compared to the standard product, almost $1 \mathrm{wt} . \%$ less water was necessary to give the new castable suitable flowability for installation (Table II). The physical properties revealed a lower porosity (AP) and higher density (BD) material which also show lower mechanical strength after different thermal treatments. In spite of the lower cold crushing strength (CCS), the new castable exhibits higher hot modulus of rupture (HMOR).

Thermal shock resistance (Figure 2) was evaluated by measuring the degree of loss of the elastic modulus (E) after different thermal shock cycles. The results revealed a slightly lower decreased of $E$ in the new product after 5 thermal shock cycles. This suggests that the main adjusts carried out in the new material resulted in less damage when compared to the standard product.

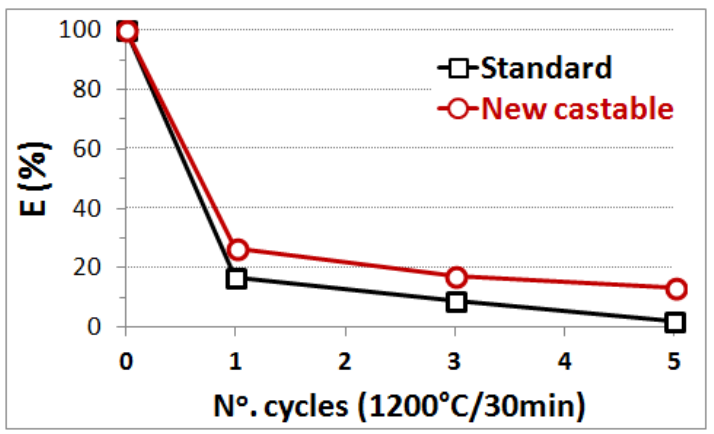

Figure 2: Castables' thermal shock resistance.

Cross sections of samples after thermal shock test were used to evaluate the castable oxidation resistance. The average oxidized area (\%) revealed a lower degree of oxidation in the new castable (Figure 3).

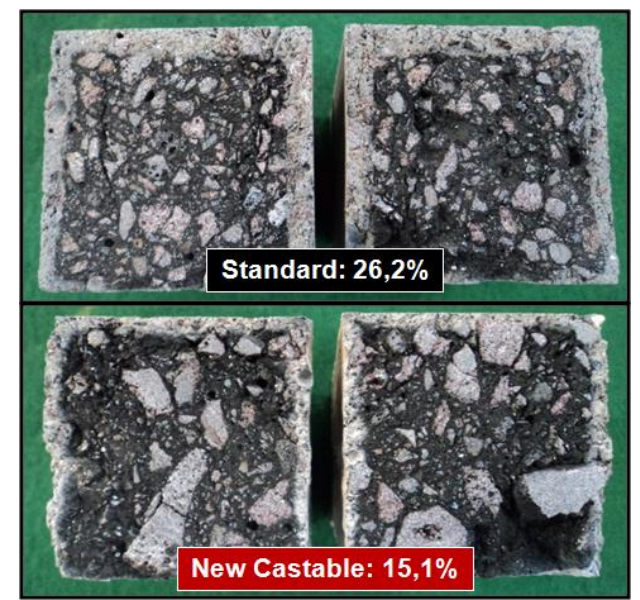

Figure 3: Cross section of castables' samples showing the oxidized area (\%).

In order to try to reproduce in a lab test the conditions that some main runners are operating nowadays and evaluate their effects in the refractory corrosion behavior, the Blast Furnace slag content used in a standard corrosion test (Test 1) was increased 50 wt.\% (Test 2). The results revealed that both standard product and the new castable suffer with the increase of the amount of slag in the Test 2 and an increase in the corrosion wear was observed when compared to Test 1 (Figure 4). The tests carried out show that even in a more severe test condition the new castable developed exhibits a lower corrosion wear (\%) in both IFT and RDT. Figure 5 shows the refractory samples after corrosion Test 2 . The pictures reveal a

* Contribuição técnica ao $44^{\circ}$ Seminário de Redução de Minério de Ferro e Matérias-primas, 15은 Simpósio Brasileiro de Minério de Ferro e 2ํ Simpósio Brasileiro de Aglomeração de Minério de Ferro, 15 a 18 de setembro de 2014, Belo Horizonte, MG, Brasil. 
significant better corrosion resistance of the new castable when in contact only with slag (RDT) and also in contact with both hot metal and slag (IFT). This data suggested that such new castable could help decrease the main runner refractory lining wear speed at both metal line (ML) and slag line (SL).
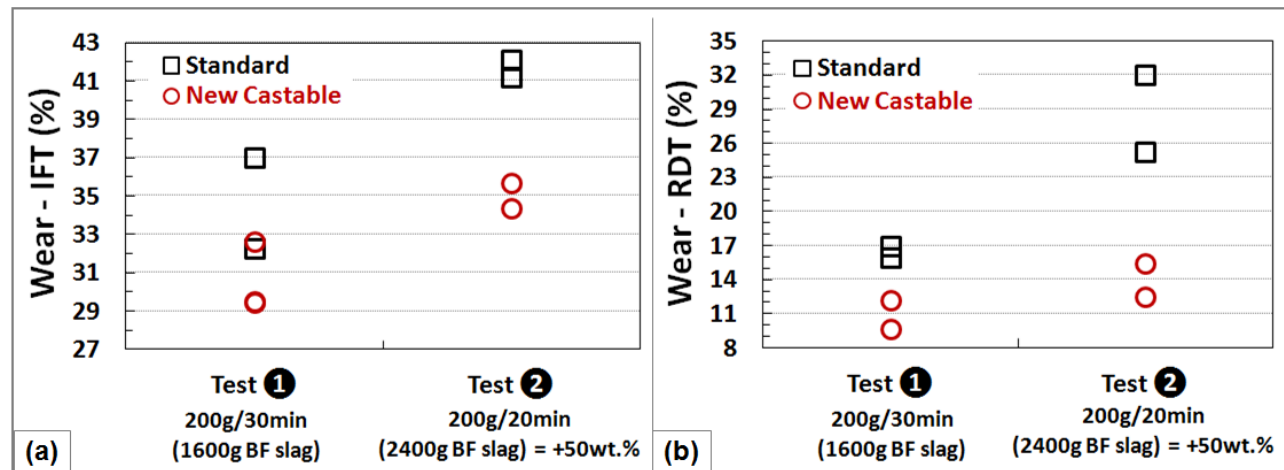

Figure 4: Corrosion resistance of the standard product and the new castable: (a) Induction Furnace Test (IFT); (b) Rotary Drum Test (RDT).

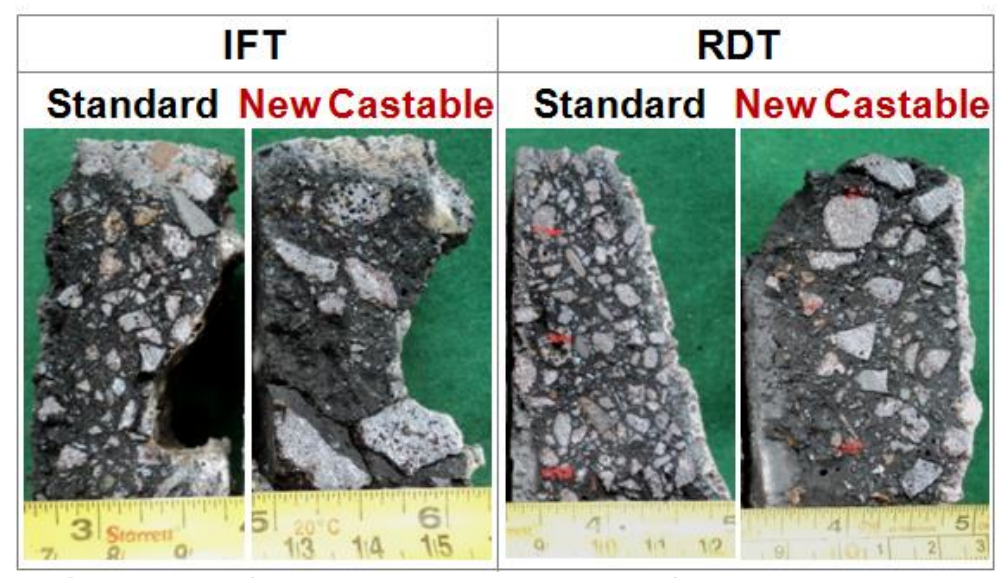

Figure 5: Refractory castable samples after corrosion Test 2.

Figure 6 shows the values of refractory lining wear speed of the main runners using the standard product or the new castable along almost one year of a 4 tap-hole (TH) Blast Furnace operation. A significant decrease in the wear speed at both metal line and slag line was observed. Figure 7 presents the typical aspects of the refractory lining by the end of the main runner's campaign. The pictures illustrate the better and safer conditions that the new castable ends the main runner's campaign at the turbulence zone $[4,5,8]$.

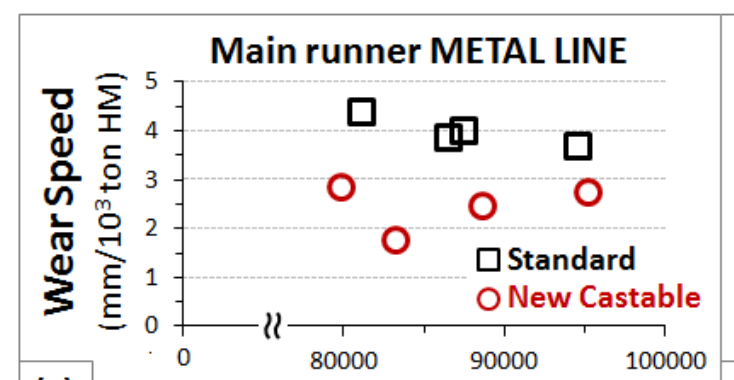

(a)

Campaign (ton HM)

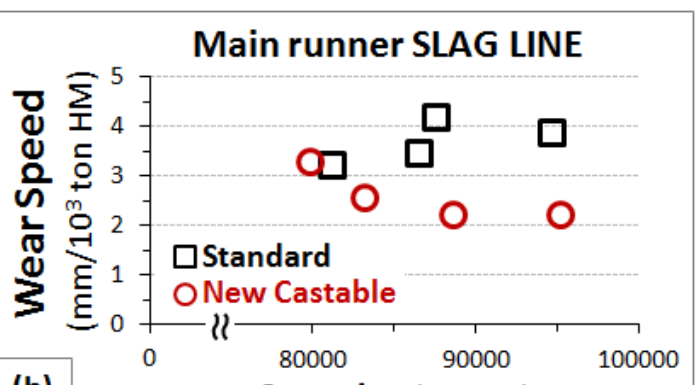

(b)

Campaign (ton $\mathrm{HM}$ )

Figure 6: Refractory lining wear speeds at the (a) metal line and (b) slag line by the end of the main runners' campaign.

* Contribuição técnica ao 44 Seminário de Redução de Minério de Ferro e Matérias-primas, 15은 Simpósio Brasileiro de Minério de Ferro e 2o Simpósio Brasileiro de Aglomeração de Minério de Ferro, 15 a 18 de setembro de 2014, Belo Horizonte, MG, Brasil. 

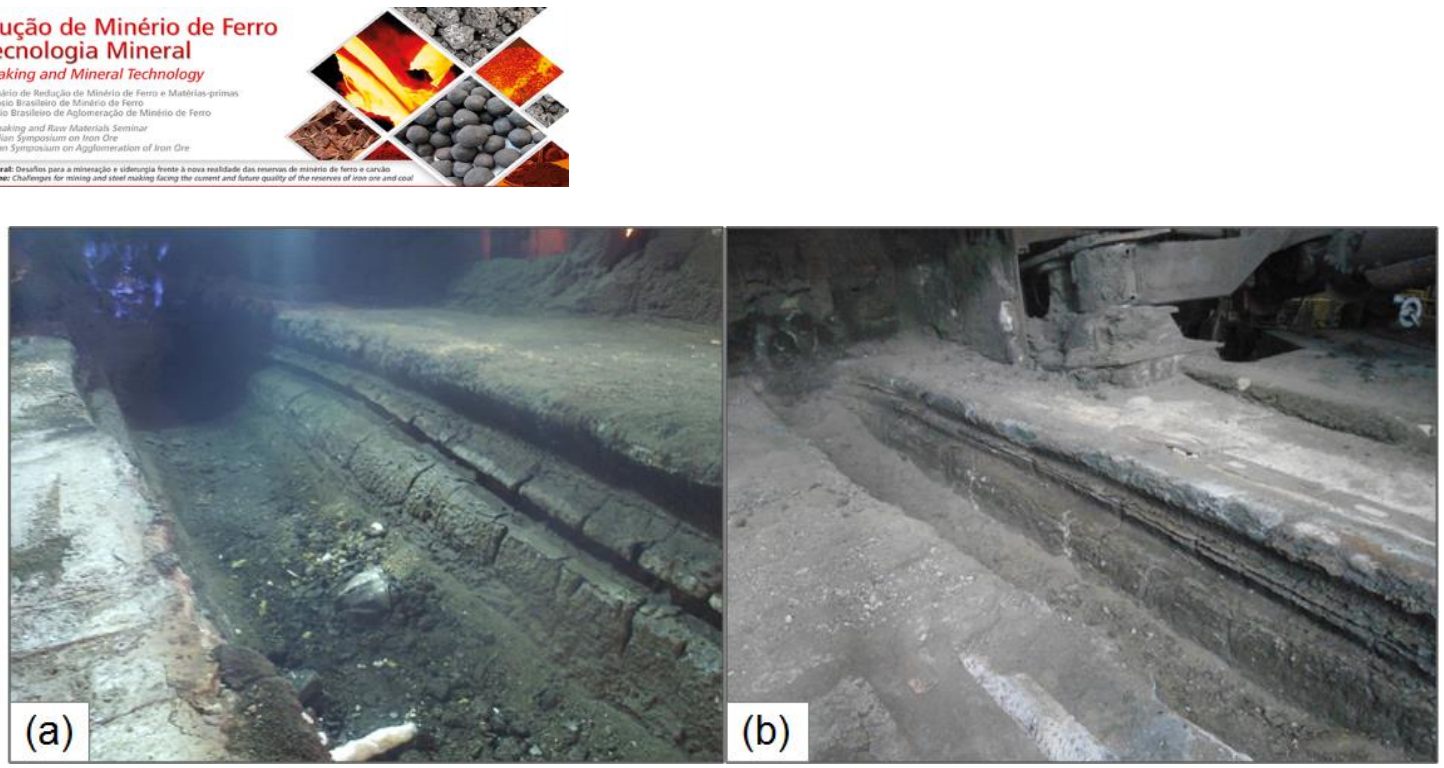

Figure 7: Typical aspect of the refractory lining at the turbulence zone by the end of the main runner campaign: (a) standard product and (b) new castable.

\section{CONCLUSION}

The development of a new refractory castable to endure the severe and unstable operating conditions that main runners are facing nowadays requires multiple adjusts in castable formulation. The results obtained in different lab tests have shown improved castable properties which suggested a potential new product. Almost one year of tests carried out in a 4TH Blast Furnace revealed a significant decrease in the wear speed at both metal line and slag line of the main runners allowing a safer casthouse operating conditions and a decrease in the total refractory consumption.

\section{REFERENCES}

1 Yasuo K, Kitamura M, Ilda T. Effect of operating conditions on Blast Furnace trough ML castable deterioration. Shinagawa Technical Report. 2011;54:15-24.

2 Ilda M, Suzuki K. Influence of Blast Furnace productivity on corrosion rate of main trough. Shinagawa Technical Report. 2011;54:25-34.

3 IIDA, M. Effect of temperature on the dissolution of Al2O3-SiC-C castables in Blast Furnace slag. Journal of the Technical Association of Refractories. 2012;32(4):271-276.

4 Domiciano VG. et al. Influência dos teores de $\mathrm{FeO}$ e $\mathrm{MnO}$ da escória no desgaste de refratários de canais de corrida de Altos-Fornos. In: 40 o Seminário de Redução de Minério de Ferro e Matérias-Primas; 19 a 22 de set. de 2010; Belo Horizonte, Brasil. São Paulo: ABM; 2010.

5 Domiciano VG. et al. Does the MgO content of the Blast Furnace slag affect the performance of main troughs?. In: UNITECR 2009; Salvador, Brazil. paper 141.

6 Yoshitomi J. et al. Local corrosion of iron trough refractories in the slag-metal interface. Aachen Proceedings; 1998. p.85-89.

7 Ilda M, Maeda E, Okamoto T. Effect of SiC oxidization on corrosion resistance of castable for metal line of blast furnace main trough. Journal of the Technical Association of Refractories. 2007;27(2):90-95.

8 Domiciano VG. et al. Desafios da ala de corrida de Altos-Fornos: Análise de falha de concreto refratário para canal de corrida. In: 43ํㅗㄴ Seminário de Redução de Minério de Ferro e Matérias-Primas; 1 a 4 de set. de 2013; Belo Horizonte, Brasil. São Paulo: ABM; 2013.

* Contribuição técnica ao 44 Seminário de Redução de Minério de Ferro e Matérias-primas, 15은 Simpósio Brasileiro de Minério de Ferro e 2o Simpósio Brasileiro de Aglomeração de Minério de Ferro, 15 a 18 de setembro de 2014, Belo Horizonte, MG, Brasil. 